\title{
Women, careers, and work-life preferences
}

\section{CATHERINE HAKIM}

Department of Sociology, London School of Economics, Houghton Street, London. WC2A 2AE, UK; email: c.hakim@lse.ac.uk

ABSTRACT There are no sex differences in cognitive ability but enduring sex differences in competitiveness, life goals, the relative emphasis on agency versus connection. Policy-makers' and feminist emphasis on equal opportunities and family-friendly policies assumes that sex discrimination is the primary source of sex differentials in labour market outcomes-notably the pay gap between men and women. However, some careers and occupations cannot be domesticated-examples are given - and this also poses limits to social engineering. Recent research shows that high levels of female employment and family-friendly policies reduce gender equality in the workforce and produce the glass ceiling. Preference theory is the only theory that can explain these new trends, the continuing pay gap and occupational segregation. Preference theory implies that there are at least three types of career rather than one. However, the differences between men and women's career goals are smaller than sometimes thought.

Society is man-made [1], and human beings are malleable, in the sense of responding to incentives and sanctions, at least in the short run (Levitt \& Dubner, 2005). It does not follow that social engineering [2] works on a completely blank slate (Pinker, 2002). Many differences between men and women that were believed to be fixed, and probably innate (Maccoby \& Jacklin, 1974), have recently been shown to be socially constructed and artificial. Most notably, once women gained access to higher education after the equal opportunities revolution, sex differences in cognitive abilities evaporated. Today, females regularly outperform males in educational qualifications obtained at secondary school level, especially during compulsory schooling (EOC \& OFSTED, 1996). Sex differences in verbal, mathematical and spatial abilities have now shrunk to small and insignificant levels (Hyde, 1996). However, some sex differences remain unchanged - notably in attitudes to sexuality, and what is often labelled as 'aggression' but extends to and includes rivalry and competitiveness as well as physical violence (Dabbs, 2000; Hyde, 1996 p. 114; Archer, 2004). A widely admired book by Gilligan (1982) argues that there are important sex differences in moral judgements affecting behaviour, which are sometimes summarised as differing emphases on agency versus connection. Reviews 
of the latest research evidence and experimental studies also conclude that many sex differences in personality and behaviour are not eroding over time; that public stereotypes of sex differences correspond closely to research findings and are hence based in reality; and that there are persistent sex differences in individualism versus collectivism (Babcock \& Laschever, 2003; Eagly, 1995; Hakim, 2004a; LorenziCioldi, 1988; Pinker, 2002; Swim, 1994).

However, many feminist scholars insist that there are no 'natural' differences between men and women, and that sex discrimination (direct and structural) is the primary reason for differences between men and women in labour market outcomes (see, for example, Bryson, 1992; Phillips, 2004). One consequence, unfortunately, is that political correctness now impedes rigorous research on the extent of sex differences in abilities, social attitudes, values, life goals and behaviour, and renders such research polemical and contentious (Eagly, 1995; Ginn et al., 1996; Hakim, 1995, 2004a). Nonetheless, there is solid evidence that men and women continue to differ, on average, in their work orientations and labour market behaviour, and that these differences are linked to broader differences in life goals, the relative importance of competitiveness versus consensus-seeking values, and the relative importance of family life and careers (Hakim, 2000, 2003a, 2004a). These differences persist long after the equal opportunities revolution of the 1960 s and 1970s gave women equal right to access higher education and all positions and careers in the labour force. However, they are differences of degree, with large overlaps between men and women. They are not fundamental qualitative differences, as often argued in the past in order to entirely exclude women from 'male' occupations such as management, the military and the professions.

The European Commission has adopted the feminist, ideological position rather than the evidence-based, scholarly perspective. It assumes that it is purely a social accident that certain careers, some of them well paid, are male-dominated and do not tolerate motherhood, long parental leaves, part-time hours of work, and familyfriendly arrangements. It has adopted as major policy goals the elimination of gender-based occupational segregation and the stubbornly stable 10-20\% difference in average earnings (the 'pay gap') between men and women in the workforce, and it insists on achieving a $70 \%$ employment rate among women despite the dramatic collapse of fertility rates in Europe. It attributes these and all other sex differences in labour market outcomes to sex discrimination, and is setting up a European Institute for Gender Equality to campaign on equality issues (European Commission, 2005a, 2005b). The International Labour Office (ILO) also takes a similar position, and argues that occupational segregation, in all its forms, is an injustice which must be eliminated (Anker, 1998). Despite more temperate language, this seems also to be the OECD's position (OECD, 2002). The usual argument is that many more women would achieve the top jobs in the workforce if employers could be persuaded to adopt family-friendly work arrangements and benefits for employees-such as parental leave, part-time working and so forth (OECD, 2001).

There seems to be no doubt that family-friendly policies are popular among many women, and make it much easier for them to combine paid jobs with family work. What is in doubt is that such policies produce gender equality in the workforce. 
The latest research evidence is that family-friendly policies do not make any major positive difference to gender equality in the labour market, as indicated by levels of occupational segregation, the pay gap and the glass ceiling. On the contrary, they exacerbate these problems. This conclusion has now been drawn by several scholars working independently (Charles \& Grusky, 2004; Hakim, 2004a; Jacobs \& Gerson, 2004). The research evidence suggests that it is unrealistic to expect that women could soon achieve half of the top jobs, that these might become fully integrated with a 50/50 split between men and women. This paper reviews this evidence, the problems, and the implications for personnel policy and careers advisory work.

\section{Can all careers be domesticated?}

One of the claims of the feminist movement, taken up by many social scientists (Jacobs \& Gerson, 2004), is that there is no good justification for the 'male' stereotype of the career: an occupation or activity that is pursued continuously, with long full-time hours, and with a high level of dedication, virtually to the exclusion of a major investment of time and energy in family work and family life. It is commonly argued, or even simply taken for granted, that all occupations can be organised and carried out on a part-time basis, or done discontinuously, so that the work can be fitted around family life. The problem is seen as being created by rigid employers, who refuse to make such changes, or lack the imagination to redesign jobs and careers in family-friendly formats [3]. In effect, the argument is that all occupations, jobs and careers can be 'domesticated' - in the sense of being redesigned into familyfriendly formats.

There is no doubt that employers are often unwilling to reorganise work arrangements due to rigidity and/or due to the higher costs entailed. Many jobs that are routinely offered on a part-time basis in a country such as the Netherlands are available exclusively as full-time jobs in southern Europe, where part-time jobs are rare. The Dutch miracle of ending high unemployment by expanding part-time jobs was the result of determined, tripartite efforts at innovation by the government, trade unions and employers (Visser \& Hemerijk, 1997). But this does not mean that all occupations and jobs can be transformed in this way, or that there are no important penalties for doing so. Space does not permit a detailed review of the limitations to work reorganisation, and of which occupations are inevitably more greedy or 'hegemonic', but some examples serve to make the point.

Some occupations and activities involve an enormous amount of travel, sometimes for long periods, often at short notice. This is obviously the case with occupations providing an on-site service of some sort (including professions like accountancy and architecture, as well as crafts such as plumbing repairs), and occupations that involve selling goods or services to a widely dispersed business clientele. Less obviously, many senior-level management jobs also involve vast amounts of travel, sometimes long distance, frequently on an unpredictable timetable, and periodically for extended periods of time away from the home base. Extensive amounts of travel are intrinsic to certain occupations, such as investment banking, news reporting, the airline and travel industries. Such occupations, and the 
careers based on them, are never going to be family-friendly. Attempts to organise family-friendly segments within them will be difficult, or the 'sedentary' versions of the job will never accumulate the same experience as the 'mobile' versions. Inevitably, the mobile worker will be promoted over the sedentary worker in such occupations and careers, because they have much wider experience and take greater responsibility.

Careers requiring extensive travel are just one example of the wider category of occupations, jobs and careers that have long and/or irregular work hours that eat into personal life and family time. Another example is public relations work. Jobs in this industry can be enormously attractive to young, single people who positively relish glamorous expense-account entertaining, late nights at business-related social events, and meeting lots of people, some of them famous. Even without extensive travel, these jobs eat into private life and steal long hours of unpaid overtime. They do not generally appeal to women with children at home, and can rarely be made familyfriendly [4].

Careers and jobs like these expose the limitations of maternity leave and parental leave schemes to change the essential nature of occupations. Most women (and some men) in such hegemonic occupations will want to move on to different types of work after they have children anyway, so there would be little point in keeping their jobs open for them. Unfortunately, there is no well-developed language for distinguishing between jobs that are 'demanding' in the intellectual sense, and those that are 'demanding' in the sense of spilling out beyond normal work hours to invade private lives - for which hegemonic, greedy or monopolising might be the more accurate labels. Jobs at the top of the hierarchy are frequently demanding on both these dimensions, as well as others.

In some other occupations, the work can readily be organised on any basis at all (part-time, intermittent, self-employed or employee, term-time only, etc.), but the competitive nature of the industry suggests that the person who can devote themselves full-time and permanently to the job is far more likely to be a high achiever than the 'dilettante' part-timer. Artistic work of all kinds is just one example here. People whose artistic output is sparse and unpredictable are generally less likely to be in demand than those with a substantial, continuous and predictable output. The same logic applies in business as well. In a competitive environment, mavericks may do well in particular niches, but they may more often be shunned as unreliable.

In many fields, the highest achievements always require imagination, dedication, creativity, and an intensive work effort that is rarely, if ever, available from the parttime or intermittent worker. Pablo Picasso, Charles Darwin, Lance Armstrong, Marie Curie and Madonna are just some of the examples here. In these fields, parttime and intermittent workers are not excluded entirely; but they are unlikely to win the top prizes.

One reason is that many full-time workers are not doing an 8-hour working day, in comparison with the part-time worker's 3-6-hour day. Many full-time workers are actually on the job, mentally or physically, for almost 24 hours a day. Their work takes priority over family life and social life, so they build up a momentum, knowledge, fitness and experience that can never be achieved by a part-time worker. 
It is no accident that today around half of the women in senior-level professional and managerial occupations in Britain are childless, even if they have married, sometimes more than once (Hakim, 2000, 2004a). Men can achieve the same effect by having a wife who is a full-time homemaker, or by remaining single - either way, they devote little or no time to domestic activities and family work.

Senior-level jobs may have relatively fixed hours most of the time, similar to other jobs. What differentiates them is the requirement to take responsibility for meeting deadlines, dealing with crises and solving unexpected problems - all of which can require (unpaid) overtime on an unpredictable and haphazard timetable [5]. Emergencies can arise in the workplace, just as in private life, and the employee who must leave on time every day at $5 \mathrm{pm}$ to collect a child from the nursery will not be dealing with them. It is these unpredictable, stressful demands for overtime hours that makes senior positions less family-friendly and less attractive to women.

It is no accident that the jobs most likely to be organised on a part-time basis are lower-grade jobs with lower earnings, relatively little responsibility, and usually with fixed hours, as well as shorter hours of work. Higher-grade occupations can also be organised on a part-time basis, but they can quickly become smaller, less responsible versions of the full-time job rather than the same job with shorter hours. Employers' requests for overtime (even for training that cannot be squeezed into part-timers' restricted hours) are generally regarded as far more stressful and unfair by part-time workers than by full-time workers.

As a general rule, jobs with time sovereignty (some freedom to choose start and finish times, some control over the length of the working day, etc.) also have the longest working hours. Jobs with unpredictable hours tend also to be jobs with longer hours. Women who want family-friendly flexible work hours usually require short and predictable hours as well. This means that other workers will be left doing the unsocial hours and overtime that mothers avoid, and they will expect to be properly compensated for their extra availability. Family-friendly flexible work arrangements are never cost-free, and employers know this.

\section{The limits to social engineering}

Both the European Commission and the ILO believe that occupational segregation can and should be eliminated (Anker, 1998; European Commission, 2005a, 2005b). They have two main reasons. First, they claim that the segregation of men and women into different occupations is the principal reason for earnings differences between men and women. Second, they argue that occupational segregation restricts people's choice of career, especially in the crucial early years of adult life. The Commission would like to see all occupations having a 50/50 male/female split, and would like to impose positive discrimination, or quotas, in order to achieve this. So far, the European Court of Justice has ruled that such policies are non-legal.

These claims and policy goals ignore the latest research results. Cross-national comparative studies by the ILO, OECD, EC (Anker, 1998; European Commission, 2002; Melkas \& Anker, 1997, 1998; OECD, 2002), and by academic scholars (see the reviews in Charles \& Grusky, 2004; Hakim, 1998, 2004a), have been overturning 
some well-established assumptions that turn out to be myths rather than fact. First, we now know that there is no direct link between occupational segregation and the pay gap; the association is coincidental rather than causal, and the two are independent social developments or constructions. Second, there is no direct causal link between economic and social development and occupational segregation, or the pay gap; modern societies do not necessarily have lower scores on these two indicators of gender equality in the workforce. The country with the lowest level of occupational segregation in the world is China, not Sweden, as so many believe. Many countries in the Far East have lower levels of occupational segregation than in western Europe. The lowest pay gap in the world is not found in Sweden, as so many claim, but in Swaziland where women earn more than men, on average, followed closely by Sri Lanka. Third, higher levels of female employment produce higher levels of occupational segregation and a larger pay gap; they do not serve to improve gender equality in the workforce, as previously assumed, but worsen it. Even within western Europe, countries with the lowest female employment rates tend to have the smallest pay gaps, as illustrated by Portugal and Spain compared to Finland and Germany.

Even more disconcerting is the evidence that family-friendly policies generally reduce gender equality in the workforce, rather than raising it, as everyone has assumed until now. This conclusion has now been drawn simultaneously by several scholars working independently (Charles \& Grusky, 2004; Hakim, 2004a; Hunt, 2002; Jacobs \& Gerson, 2004). In particular, Sweden's generous family-friendly policies have created a larger glass ceiling problem than exists in the USA, where there is a general lack of such policies (Albrecht et al., 2003; Henrekson \& Dreber, 2005). Women are more likely to achieve senior management jobs in the USA than in Sweden: $11 \%$ versus $1.5 \%$, respectively (Rosenfeld \& Kalleberg, 1990; see also Henrekson \& Dreber, 2005; Wright et al., 1995). There is no doubt that familyfriendly policies help women to combine paid jobs with family work. What they do not do is solve the problem of gender inequality in the workforce.

Analyses to date have often failed to distinguish between horizontal occupational segregation and vertical occupational segregation. Horizontal occupational segregation exists when men and women choose different careers - for example, men are carpenters while women are cooks. Vertical occupational segregation exists when men dominate higher-grade higher-paid occupations and women are concentrated in lower-grade, lower-paid occupations in the same area of activity: for example, men are managers while women are secretaries, men are surgeons while women are nurses. Most studies have focused on horizontal occupational segregation, which many would regard as in some sense natural, or at least not noxious, and where there is no obvious link to earnings differences. Vertical occupational segregation is harder to measure, so is less studied. It has an obvious link to earnings differences between men and women, but these would generally be regarded as justified rather than sexist: in capitalist economies it is self-evident that managers earn more than their secretaries. The crucial question is why are women less likely to achieve the top jobs: lack of interest? or active exclusion? Analyses of macro-level national statistical data on the workforce cannot tell us anything at all about the social processes going on at 
the micro-level. It is wrong to assume that a low percentage of women in highergrade jobs is necessarily due to sex discrimination alone.

\section{Strategic case studies of the professions and management}

Case studies of women who have achieved high status professional and managerial jobs tell us a lot more about the social processes involved. They show, for example, that such women have greatly reduced, or even eliminated, their work-life balance problems by remaining childless, in about half of all cases, or by lower fertility, as illustrated by one-child families. In contrast, almost all their male colleagues are married, with several children, but also with wives who typically remain full-time homemakers, so that the couple operates complete role segregation in the family division of labour.

Another myth that has been overturned by recent research is the notion that women bring distinctively feminine approaches to management and top jobs. As Wajcman $(1996,1998)$ has shown, there are no visible gender differences in styles of management. Female managers differ from male managers in their personal characteristics and family lives, but not in the way that they do the job.

Case studies of professions that have become fully integrated, employing equal numbers of men and women are also revealing (Hakim, 1998, 2003a). Across modern societies, pharmacy now employs equal numbers of men and women, and also employs disproportionate numbers of ethnic minority people. Due to chronic labour shortages, it is widely agreed that the profession is completely free of sex and race discrimination. Studies of the profession in the USA, Canada, Britain, and other European countries show a large degree of job segregation within the occupation. Women gravitate towards jobs that are local, can be done part-time or for short periods, and to jobs with fixed hours of work that can be fitted around family life. Men in the profession gravitate towards ownership of independent pharmacies, which entail the long work hours and additional responsibilities of self-employment and running a small business. Other men work towards management jobs in the large retail chains, again accepting long hours and more overtime in return for higher earnings. Given the absence of sex discrimination in the profession, it is clear that women are free to choose (even impose) whatever working arrangements they prefer. In Britain, there is no earnings difference between full-time and part-time workers in the profession, but there is a large $27 \%$ earnings differential between women and men working full-time, close to the average pay gap for all fully integrated professions (Hakim, 1998). Case study research shows that these sex differentials in the professions are due to substantively different work orientations among men and women, even among university graduates (Hakim, 2000, 2004a), and hence to very different career paths.

\section{Preference theory}

The latest research results on women's position in the labour market are making old theories, especially those focusing on patriarchy and sex discrimination, out of date. 
We need new theories for the 21 st century, theories that take account of, and are consistent with, the newest research findings. Preference theory does this.

Preference theory is a new theory for explaining and predicting women's choices between market work and family work, a theory that is historically-informed, empirically-based, multidisciplinary, prospective rather than retrospective in orientation, and applicable in all rich modern societies (Hakim, 2000). Lifestyle preferences are defined as causal factors which thus need to be monitored in modern societies. In contrast, other social attitudes, such as patriarchal values, are either unimportant as predictors of behaviour, or else have only a very small marginal impact, by creating a particular climate of public opinion on women's roles (Hakim, 2003b, 2004b).

Preference theory predicts a polarisation of work-lifestyles, as a result of the diversity in women's sex-role preferences and the three related models of family roles. It argues that in prosperous modern societies, women's preferences become a central determinant of life choices - in particular the choice between an emphasis on activities related to children and family life or an emphasis on employment and competitive activities in the public sphere. The social structural and economic environment still constrains women's choices to some extent, but social structural factors are of declining importance - most notably social class [6]. Preference theory forms part of the new stream of sociological theory that emphasises ideational change as a major cause of social behaviour. Giddens' theory of reflexive modernity emphasises individualisation as the driving force for change in late modernity. Individualisation frees people from the influence of social class, nation, and family. Agency becomes more important than the social structure as a determinant of behaviour, even when 'structure' is understood in Giddens' sense of rules and resources. Men and women not only gain the freedom to choose their own biography, values and lifestyle, they are forced to make their own decisions because there are no universal certainties or collectively agreed conventions, no fixed models of the good life, as in traditional or early modern industrial societies (Beck et al., 1994; Giddens, 1991). Preference theory can be seen as an empirically-based statement of the choices women and men actually make in late modernity. It contrasts with economic theories of the family (Becker, 1991) that assume that women and men form homogeneous groups, with contrasting goals and preferences, which make some family division of labour optimal and efficient for all couples, and produces sex differences in investments in careers. In sum, preference theory predicts diversity in lifestyle choices, and even a polarisation of lifestyles among both men and women.

The diversity of family models and lifestyle choices is hidden in variable-centred analysis, which tends to focus on the average outcome, the modal pattern and the central tendency. The diversity of ideal family models and lifestyle preferences only emerges clearly in studies using person-centred analysis (Cairns et al., 1998; Magnusson, 1998), which is still uncommon.

Preference theory specifies the historical context in which core values become important predictors of behaviour. It notes that five historical changes collectively produce a qualitatively new scenario for women in affluent modern societies in the 21 st century, giving them options that were not previously available (Table 1). 
TABLE 1. The four central tenets of preference theory.

1. Five separate historical changes in society and in the labour market which started in the late 20th century are producing a qualitatively different and new scenario of options and opportunities for women. The five changes do not necessarily occur in all modern societies, and do not always occur together. Their effects are cumulative. The five causes of a new scenario are:

- the contraceptive revolution which, from about 1965 onwards, gave sexually active women reliable control over their own fertility for the first time in history;

- the equal opportunities revolution, which ensured that for the first time in history women had equal right to access to all positions, occupations and careers in the labour market. In some countries, legislation prohibiting sex discrimination went further, to give women equal access to housing, financial services, public services, and public posts;

- the expansion of white-collar occupations, which are far more attractive to women that most blue-collar occupations;

- the creation of jobs for secondary earners, people who do not want to give priority to paid work at the expense of other life interests; and

- the increasing importance of attitudes, values and personal preferences in the lifestyle choices of affluent modern societies.

2. Women are heterogeneous in their preferences and priorities on the conflict between family and employment. In the new scenario they are therefore heterogeneous also in their employment patterns and work histories. These preferences are set out, as ideal types, in Table 2. The size of the three groups varies in rich modern societies because public policies usually favour one or another group.

3. The heterogeneity of women's preferences and priorities creates conflicting interests between groups of women: sometimes between home-centred women and work-centred women, sometimes between the middle group of adaptive women and women who have one firm priority (whether for family work or employment). The conflicting interests of women have given a great advantage to men, whose interests are comparatively homogeneous; this is one cause of patriarchy and its disproportionate success.

4. Women's heterogeneity is the main cause of women's variable responses to social engineering policies in the new scenario of modern societies. This variability of response has been less evident in the past, but it has still impeded attempts to predict women's fertility and employment patterns. Policy research and future predictions of women's choices will be more successful in future if they adopt the preference theory perspective and first establish the distribution of preferences between family work and employment in each society.

Source: Hakim (2000).

Reviews of the research evidence for the last three decades, particularly for the USA and Britain (Hakim, 2000, 2004a), show that once genuine choices are open to them, women choose between three different lifestyles: home-centred, work-centred or adaptive (Table 2). These divergent preferences are found at all levels of education, and in all social classes. Social class becomes less important than motivation, personal life goals, attitudes and values.

The three preference groups are set out, as sociological ideal types, in Table 2, with estimates of the relative sizes of the three groups in societies, such as Britain and the USA, where public policy does not bias the distribution. In this case, the 
TABLE 2. Classification of women's work-lifestyle preferences in the 21 st century.

\begin{tabular}{llc}
\hline Home-centred & Adaptive & Work-centred \\
$20 \%$ of women & $60 \%$ of women & $20 \%$ of women \\
varies $10-30 \%$ & varies $40-80 \%$ & varies $10-30 \%$ \\
\hline
\end{tabular}

Family life and children are the This group is most diverse and Childless women are main priorities throughout life. $\begin{array}{r}\text { includes women who want to } \\ \text { combine work and family, plus }\end{array}$ concentrated here. Main priority combine work and family, plus in life is employment or drifters and unplanned careers. equivalent activities in the public arena: politics, sport, art, etc.

Prefer not to work.

Qualifications obtained as cultural capital.
Want to work, but not totally committed to work career.

Qualifications obtained with the intention of working.

Committed to work or equivalent activities.

Large investment in qualifications/training for cultural capital employment/ other activities.

Responsive to economic opportunity, political opportunity, artistic opportunity, etc. Not responsive to social/ family policy. propaganda, economic cycle/ recession/growth, etc., including: income tax and social welfare benefits, educational policies, school timetables, child care services, public attitude towards working women, legislation promoting female employment, trade union attitudes to working women, availability of part-time work and similar work flexibility, economic growth and prosperity, and institutional factors generally.

Family values: caring, sharing, Compromise between two non-competitive, communal, conflicting sets of values

Marketplace values: competitive rivalry, achievement orientation, individualism, excellence focus on cohesion

Source: Hakim (2000).

distribution of women across the three groups corresponds to a 'normal' statistical distribution of responses to the family-work conflict [7]. In practice, in most societies, public policy is biased towards one group or another, by accident or by design, so that the exact percentages vary between modern societies, with inflated numbers of work-centred women or home-centred women. 
Work-centred women are in a minority, despite the massive influx of women into higher education and into professional and managerial occupations in the last three decades. Work-centred people (men and women) are focused on competitive activities in the public sphere - in careers, sport, politics, or the arts. Family life is fitted around their work, and many of these women remain childless, even when married. Qualifications and training are obtained as a career investment rather than as an insurance policy, as in the adaptive group. The majority of men are workcentred, compared to only a minority of women, even women in professional occupations (Hakim, 1998, 2003a). Preference theory predicts that men will retain their dominance in the labour market, politics and other competitive activities, because only a minority of women are prepared to prioritise their jobs (or other activities in the public sphere) in the same way as men. In the long run, it is workcentred people who are most likely to survive, and become high achievers, in greedy occupations.

Adaptive women prefer to combine employment and family work without giving a fixed priority to either. They want to enjoy the best of both worlds. Adaptive women are generally the largest group among women, and are found in substantial numbers in most occupations. Certain occupations, such as schoolteaching, are attractive to women because they facilitate a more even work-family balance. The great majority of women who transfer to part-time work after they have children are adaptive women, who seek to devote as much time and effort to their family work as to their paid jobs. In some countries (such as the USA and southern European countries), and in certain occupations, part-time jobs are still rare, so women must choose other types of job, if they work at all. For example, seasonal jobs, temporary work, or school-term-time jobs all offer a better work-family balance than the typical full-time job, especially if commuting is also involved. When flexible jobs are not available, adaptive women may take ordinary full-time jobs, or else withdraw from paid employment temporarily. Adaptive people are the group interested in schemes offering work-life balance and family-friendly employment benefits, and will gravitate towards careers, occupations and employers offering these advantages.

The third group, home-centred or family-centred women, is also a minority, and a relatively invisible one in the Western world, given the current political and media focus on working women and high achievers. Home-centred women prefer to give priority to private life and family life after they marry. They are most inclined to have larger families, and these women avoid paid work after marriage unless the family is experiencing financial problems. They do not necessarily invest less in qualifications, because the educational system functions as a marriage market as well as a training institution. Despite the elimination of the sex differential in educational attainment, an increasing percentage of wives in the USA and Europe are now marrying a man with substantially better qualifications, and the likelihood of marrying a graduate spouse is hugely increased if the woman herself has obtained a degree (Hakim, 2000; Blossfeld \& Timm, 2003) [8]. This may be why women remain less likely to choose vocational courses with a direct economic value, and are more likely to take courses in the arts, humanities or languages, which provide cultural capital but have lower 
earnings potential. This group of workers is most likely to drop out of greedy careers relatively early in adult life.

It is necessary to differentiate between a person's core values and life goals, and the multitude of topics on which public opinion data are collected. There is an important theoretical and methodological distinction between personal goals and preferences, which are causal in relation to individual behaviour, and general social attitudes and societal norms, which are usually non-causal (Hakim, 2003b, 2004b). There is a distinction between choice and approval, between personal goals and public beliefs, between what is desired by the survey respondent for their own life and what is considered desirable in society in general. The two are not coterminous, and there is only a weak link between societal norms and personal preferences and goals (Hakim, 2000). For example, people may agree that it would be better if everyone stopped smoking, yet choose to smoke themselves.

\section{Implications for policy and practice}

Preference theory provides a different explanation for the continuing pay gap and occupational segregation. Moreover, it predicts that they will persist in the $21 \mathrm{st}$ century, that men will continue to outnumber women in the top jobs, simply because they try much harder to get them. The majority of working women seek a large degree of work-life balance (Hakim, 2005), certainly more than men do. Women are more likely to ask for shorter work hours than to ask for higher pay or promotion (Babcock \& Laschever, 2003).

It can be objected that the sex differences identified in reviews of research on personality and behaviour are often small, so should not matter. This argument confounds macro-level and micro-level perspectives. It is true that many sex differences today are relatively small, even if persistent, in studies at the aggregate, national level. But differences between people are much larger at the micro-level, and can be fundamentally important at the individual level. Selecting people for jobs or careers is done on an individual basis, and even quite small perceived differences between individuals can make the difference between being shortlisted or not, between winning the job or promotion or not. What is statistically small and relatively unimportant in a national study can still explain cumulative differences in success rates at the individual level, leading to major sex differences in careers.

There are wide implications for national social policy, for employer and trade union policies, and for careers advisors. Elsewhere I have proposed a fundamental reorientation of social policy in the European Union and in member states (Hakim, 2000). At present, equal opportunities policies assume that all women are careerist in their work orientations, and that more support needs to be given to working mothers, in the form of public childcare services and time off from work. If only a minority of women are in fact careerist, and many of them are childless, then policy is at present misdirected, as well as overlooking people with other life goals.

The most general requirement is for policies to be even-handed between the three groups of workers, rather than assuming that one-size-fits-all policies suit everyone. At present, the bias seems to be towards careerist women with children, a 
tiny minority of all workers. Gender-neutral policies require a sharp move away from the current focus on working mothers. Just one example is the new law in the Netherlands giving all workers the right to ask to work part-time hours, for any reason or none. There is no reason to focus such special privileges on working mothers only, thus prompting jealousy and resentment among other groups of employees. Similarly, employers should offer long (unpaid) career breaks to all employees, rather than parental leave for new mothers only. Cafeteria benefits provides one way to ensure that there is something for everyone, and no one loses out.

We should also accept that there are at least three types of career rather than just one: the truncated career that probably ends with (delayed) marriage or babies, the adaptive career that demands a large element of work-life balance over the lifecycle as a whole, and what I have called above the 'hegemonic' or 'greedy' career that can easily become all-consuming, especially at senior levels. The evidence from a recent national survey in Britain (Hakim, 2003a) is that all three types of worker can be found working side by side in the same occupations, albeit in different types of job. Equal opportunities legislation allows women to choose any type of occupation, without having to squeeze into a small number of family-friendly occupations, such as teaching, as in the 20th century. Whatever their ambitions and lifeplans, women can now choose occupations far more freely than in the past. However, this diversity in the workforce does pose new problems for personnel managers.

For careers counsellors, this is perhaps the most startling conclusion: homecentred women seem to be just as likely to seek careers as pharmacists, lawyers, PR specialists or IT specialists as work-centred people. However, the kinds of jobs they do, and the level of promotion sought in each occupation, will differ from those chosen by work-centred people and adaptive people. It is career patterns and longterm ambitions that differ between the three groups rather than occupational choices. This conclusion is based on just one British survey, so needs to be confirmed by other studies and data for other countries, but it is consistent with case study research on the professions, as noted above.

Finally, we should also remember that many men are adaptive in their worklifestyle preferences. Work-centred men appear to be in the majority, but they are not the only type [9]. This is a hidden source of diversity in employee attitudes to work and careers, which extends and reinforces female diversity. The scope for unisex policies that recognise and value all three types of career, and benefit men and women equally, is far greater than feminist campaigners have imagined.

\section{Notes}

[1] The current fashion is to say that it is 'socially constructed', and duck the question of who has had most influence on contemporary social structures. In practice, men have so far been the dominant force in the development of social institutions and the character of public life, even if women have generally been dominant in shaping family life. It is therefore still reasonable to view society as manmade, predominantly. 
[2] Social engineering typically consists of legislation and policies designed to alter behaviour, by changing the incentives and sanctions applied to particular behaviours. Laws prohibiting sex discrimination and equal opportunities policies are an obvious example (Hakim, 2004a).

[3] For example, Julie Mellor, the head of the Equal Opportunities Commission in Britain, when announcing her resignation in July 2005, argued that the lack of flexible work arrangements at every level of the economy was due to employers' 'lack of creativity and a lack of courage to try something they haven't tried before'.

[4] A polemical but nonetheless useful summary of the research evidence on explanations for the pay gap, and why occupations chosen by men generally pay more than occupations chosen by women, is given in Why Men Earn More (Farrell, 2005). A less polemical review of this research literature is given in Hakim (2004).

[5] For example, when the Enron scandal broke, senior executives working in risk management, insurance, and other parts of the financial services industry found themselves working continuously for 48 hours or longer, sleeping at the office until their position was clarified. Similarly, hospital surgeons can find themselves working 'around the clock' after a major bombing incident or transport accident.

[6] The declining importance of social class as a predictor of behaviour and choices in the 21 st century is most obvious in politics - as illustrated by the fact that personal values, rather than social class, differentiated support for $\mathrm{Al}$ Gore and George W. Bush in the closely contested USA election of 2000 .

[7] The distribution set out in Table 2 is based on an extensive review of the empirical evidence for the last two decades presented in Hakim (2000), and has been reconfirmed by subsequent national survey research in European countries (Hakim, 2003a) and in the USA (Hattery, 2001).

[8] Studies of 'self-service' marriage markets in modern societies show that most women are concerned to marry a man with equal or better education (and thus equal or better earnings potential), whereas most men place far less weight on this criterion in their choice of spouse. The majority of men with education beyond basic secondary education marry women with less education, because men give more weight to physical attractiveness (Hakim, 2000).

[9] National surveys in Britain and Spain suggest that just over half of men are work-centred, and the rest are adaptives, with home-centred men too few to be counted (Hakim, 2003a). A more recent survey in Belgium (Flanders) found three-quarters of all prime age men (those aged 20-50 years) to be work-centred; only one-quarter were adaptives, and the home-centred group was so tiny as to be virtually invisible at around $1 \%$ of the age group (Corijn \& Hakim, forthcoming).

\section{References}

Albrecht, J., Björklund, A. \& VRoman, S. (2003). Is there a glass ceiling in Sweden? fournal of Labor Economics, 21, 145-177.

Anker, R. (1998). Gender and Fobs: Sex Segregation of Occupations in the World. Geneva: ILO.

ARCHER, J. (2004). Sex differences in aggression in real-world settings: A meta-analytic review. Review of General Psychology, 8, 291-322.

Babcock, L. \& Laschever, S. (2003). Women Don't Ask: Negotiation and the Gender Divide. Princeton, NJ: Princeton University Press.

Beck, U., Giddens, A. \& Lash, S. (1994). Reflexive Modernization. Cambridge: Polity Press.

Becker, G.S. (1991). A Treatise on the Family. Cambridge, MA: Harvard University Press.

Blossfeld, H-P. \& Timm, A. (2003). Who Marries Whom? Educational Systems as Marriage Markets in Modern Societies. Dordrecht: Kluwer Academic.

Bryson, V. (1992). Feminist Political Theory. London: Macmillan.

Cairns, R.B., Bergman, L.R. \& Kagan, J. (Eds). (1998). Methods and Models for Studying the Individual. London \& Thousand Oaks, CA: Sage.

Charles, M. \& Grusky, D.B. (2004). Occupational Ghettos: the Worldwide Segregation of Women and Men. Stanford, CA: Stanford University Press.

Corijn, M. \& HaKim, C. (forthcoming). Searching for policy levers to raise fertility. 
Dabbs, J.M. (2000). Heroes, Rogues, and Lovers: Testosterone and Behaviour. New York: McGraw-Hill.

EAgly, A.H. (1995). The science and politics of comparing women and men. American Psychologist, 50, 145-158 [followed by Comments by Hyde \& Plant, Marecek, and Buss, and a Response by Eagly, 159-171].

EOC \& OFSTED. (1996). The Gender Divide: Performance Differences Between Boys and Girls at School. Manchester: EOC.

European Commission. (2002). Employment in Europe. Luxembourg: OOPEC.

European Commission, Directorate General for Employment, Social Affairs and Equal Opportunities. (2005a). Social Agenda, 11, 15-24.

European Commission, Directorate General for Employment, Social Affairs and Equal Opportunities. (2005b). Confronting Demographic Change: a New Solidarity Between the Generations-Green Paper. Luxembourg: OOPEC.

FARrell, W. (2005). Why Men Earn More. New York: AMACOM for the American Management Association.

Giddens, A. (1991). Modernity and Self-Identity: Self and Society in Late Modern Age. Cambridge: Polity Press.

Gilligan, C. (1982). In a Different Voice: Psychological Theory and Women's Development. Cambridge, MA \& London: Harvard University Press.

Ginn, J., Arber, S., Brannen, J., Dale, A., Dex, S., Elias, P., Moss, P., Pahl, J., Roberts, C., Rubery, J. \& Breugel, I. (1996). Feminist fallacies: a reply to Hakim on women's employment and whose myths are they anyway: a comment. British fournal of Sociology, 47, 167-177.

Hakim, C. (1995). Five feminist myths about women's employment. British fournal of Sociology, 46, 429-455.

Hakim, C. (1998). Social Change and Innovation in the Labour Market. Oxford: Oxford University Press.

Hakim, C. (2000). Work-Lifestyle Choices in the 21st Century: Preference Theory. Oxford: Oxford University Press.

Hakim, C. (2003a). Models of the Family in Modern Societies: Ideals and Realities. Aldershot: Ashgate.

HAKIM, C. (2003b). Public morality versus personal choice: the failure of social attitude surveys. British fournal of Sociology, 54, 339-345.

Haкim, C. (2004a). Key Issues in Women's Work: Female Diversity and the Polarisation of Women's Employment. London: GlassHouse Press.

Hakim, C. (2004b). Lifestyle preferences versus patriarchal values: causal and non-causal attitudes. In: Giele, J.Z. \& Holst, E. (Eds), Changing Life Patterns in Western Industrial Societies (pp. 69-91). Oxford: Elsevier.

Hakim, C. (2005). Sex differences in work-life balance goals. In: Houston, D. (Ed.), Work-Life Balance in the Twenty-First Century (pp. 55-79). London: Palgrave Macmillan.

Hattery, A. (2001). Women, Work and Family. Thousand Oaks, CA: Sage.

Henrekson, M. \& Dreber, A. (2005). Female Career Success: Institutions, Path Dependence and Psychology. Stockholm: Stockholm School of Economics Department of Economics.

HunT, J. (2002). The transition in East Germany: when is a ten-point fall in the gender wage gap bad news? Fournal of Labor Economics, 20, 148-169.

Hyde, J.S. (1996). Where are the gender differences? Where are the gender similarities? In: Buss, D.M \& Malamuth, N.M. (Eds), Sex, Power, Conflict (pp. 107-118). New York: Oxford University Press.

Jacobs, J.A. \& Gerson, K. (2004). The Time Divide: Work, Family, and Gender Equality. Cambridge, MA: Harvard University Press.

Levitt, S. \& Dubner, S.J. (2005). Freakonomics. London: Allen Lane.

Lorenzi-Cioldi, F. (1988). Individus Dominants et Groupes Dominés: Images Masculines et Feminines. Grenoble: Presses Universitaires de Grenoble.

Maccoby, E.E. \& Jacklin, C.N. (1974). The Psychology of Sex Differences. Stanford, CA: Stanford University Press. 
Magnusson, D. (1998). The logic and implications of a person-oriented approach. In: CAIRNs, R.B., Bergamn, L.R. \& Kagan, J. (Eds), Methods and Models for Studying the Individual (pp. 33-64). London \& Thousand Oaks, CA: Sage.

Melkas, H. \& ANKeR, R. (1997). Occupational segregation by sex in Nordic countries: an empirical investigation. International Labour Review, 136, 341-363.

Melkas, H. \& ANker, R. (1998). Gender Equality and Occupational Segregation in Nordic Labour Markets. Geneva: International Labour Office.

OECD (2001). Balancing work and family life: helping parents into paid employment. In: Employment Outlook (pp. 129-166). Paris: OECD.

OECD (2002). Women at work. In: Employment Outlook (pp. 61-125). Paris: OECD.

Phillips, A. (2004). Defending equality of outcome. Fournal of Political Philosophy, 12, 1-19.

Pinker, S. (2002). The Blank Slate: Modern Denial of Human Nature. London: Allen Lane.

Rosenfeld, R.A. \& KALLEBerg, A.L. (1990). A cross-national comparison of the gender gap in income. American Fournal of Sociology, 96, 69-106.

SwIM, J.K. (1994). Perceived versus meta-analytic effect sizes: an assessment of the accuracy of gender stereotypes. Fournal of Personality and Social Psychology, 66, 21-36.

Visser, J. \& HemerIJcK, A. (1997). A Dutch Miracle - Fob Growth, Welfare Reform and Corporatism in the Netherlands. Amsterdam: Amsterdam University Press.

WajCMAN, J. (1996). Desperately seeking differences: is management style gendered? British fournal of Industrial Relations, 34, 333-349.

Wajcman, J. (1998). Managing Like a Man: Women and Men in Corporate Management. Philadelphia, PA: Pennsylvania University Press.

Wright, E.O., BAXTER, J. \& Birkelund, G.E. (1995). The gender gap in workplace authority: a crossnational study. American Sociological Review, 60, 407-435.

(Accepted 15 fanuary 2006) 